\title{
Enhancement of Mechanical Properties of Lightweight Foamed Concrete using Fibermesh
}

\author{
Anisah Mat Serudin, Md Azree Othuman Mydin, Abdul Naser Abdul Ghani
}

\begin{abstract}
Foamed concrete is one of the lightweight concretes that has been investigated widely due to its potential use as a building element as well as due to its benefits, which are low in self weight, more durable, self-compacting and has excellent thermal insulation properties. The major limitation of this material is because of its characteristics which are weak in tension and suffers high shrinkage. Therefore, the introduction of fiber in foamed concrete becomes a popular research focus among researchers in conducting a study since it can aid in overcoming this problem. Thus, this research was performed to investigate the mechanical properties of foamed concrete with the enclosure of fibermesh. Fibermesh with a size of $160 \mathrm{~g}$ weight per square meter was examined on three densities of foamed concrete $(800 \mathrm{~kg} / \mathrm{m3}, 1100 \mathrm{~kg} / \mathrm{m3}, 1400 \mathrm{~kg} / \mathrm{m3})$. The cement-sand used in this study was constantly maintained at 1:1.5 and the water to cement ratio was fixed at 0.45. Moreover, this study also explored the improvement of foamed concrete strength from without any addition of fiber (control) to 1, 2, and 3 layer(s) of fibermesh enclosure. There were three experimental tests conducted to determine the foamed concrete strength which are compressive strength test, flexural test, and splitting tensile test. The experimental results showed that, foamed concrete gave the highest strength results at a density of $1400 \mathrm{~kg} / \mathrm{m} 3$ with the 1 enclosure of 3 layers of fibermesh while the lowest strength was attained at $800 \mathrm{~kg} / \mathrm{m} 3$ density with no addition of fiber (control specimen). The positive improvement in foamed concrete strength obviously showed after enclosure of fibermesh compared to the plain foamed concrete, where at density of $1400 \mathrm{~kg} / \mathrm{m} 3$ with 3 layers enclosure of fibermesh, $96 \%$ of changes was recorded in the compressive strength test while $332 \%$ was shown in the flexural strength test and $421 \%$ was recorded in the splitting tensile test.
\end{abstract}

Keywords: Foamed concrete, fibermesh, compressive strength, flexural strength, splitting tensile strength.

\section{INTRODUCTION}

These days, the construction industry in Malaysia is increasingly in need of attaining more energy efficient, environmentally friendly and reasonably priced building components and materials[1]. As far as the construction sector in concerned, permanent structures that includes selfweight accounts for a very large proportion of the total load of structures. Even though conventional concrete is broadly utilized in applications ranging from buildings to pavements, and bridges to dams, the consumption of coarse

Revised Manuscript Received on June 22, 2019.

Anisah Mat Serudin, School of Housing, Building and Planning, Universiti Sains Malaysia, 11800, Penang, Malaysia

Md Azree Othuman Mydin, School of Housing, Building and Planning, Universiti Sains Malaysia, 11800, Penang, Malaysia

Abdul Naser Abdul Ghani, School of Housing, Building and Planning, Universiti Sains Malaysia, 11800, Penang, Malaysia aggregates in concrete inclines to add on to the self-weight of the concrete, eventually putting redundant permanent load on the structural element. Introduction of foamed concrete in the construction industry can aid in reducing dead load in building structures[2]. This is because foamed concrete has two times lower density than conventional concrete. Generally, foamed concrete is a slurry mortar that contains $20 \%$ of air-voids volume entrapped in mortar which makes it lighter than conventional concrete[3]. This material gains more interest among researchers due to its characteristics which are more durable, low self-weigh, easy to construct, can reduce labour cost during construction period, etc.

Even though foamed concrete has a low self-weight, there are many drawbacks reported from previous researchers. The major problem of using this material is that it is very weak in tensile due to numerous micro-cracks contained in it, where it begins to propagate in the cement matrix when the load is applied [4]. The foamed concrete cannot support the tensile developed due to the applied forces without inclusion of reinforcing element in the tensile zone. Meheddene et al. [5] stated that the addition of fibre assisted in arresting the propagation of the micro-cracks and macrocrack under flexural load.

Basically, foamed concrete is hardly utilized as a structural element. Brady etal. [6], reported that the application of foamed concrete started to be recognized in construction work after the Netherlands started to use it as filling voids and for ground engineering application in the late 1970s. The success of a full-scale trial use of foamed concrete for trench reinstatement in the UK was the stepping-stone of foamed concrete usage in the construction industry. For the last few decades, the application of foamed concrete was widely used as non-structural and semistructural material in building. Amran et al. [7] also stated that, foamed concrete has the potential of being used as a structural material.

Thus, many researchers started to come out with studies to verify that the implementation of fibre in foamed concrete can contribute to strength enhancement of foamed concrete compared to plain foamed concrete (no fibre addition). In previous studies, many researchers used fibre as an inclusion in their experiment. Even though the inclusion of fibre showed positive impact in foamed concrete mechanical properties, nevertheless, excessive utilization of fibre may lead to a segregation effect in the cementmatrix. In addition, a higher content of fibre utilization in foamed concrete is not conceivable since it will lead to a balling effect during the mixing process and influence the compressive strength of foamed concrete holistically. 
In recent years, external wrapping of concrete using fibre reinforced polymers (FRP) has become popular for the strengthening of concrete. FRP possess excellent mechanical properties, it comprises of resistance to corrosion, outstanding durability performance, impact resistance, high strength-to-weight ratio, ease of installation, exceptional fatigue behaviour, fire resistance, creep, and stiff as compared to traditional reinforcing materials such as steel and cementitious materials, which can result in it being less labour-intensive [8]. Based on the research that has been conducted by Noosidi and Hazren [9], they found that the application of fibre wrapped concrete enhanced the compressive and flexural strength while less significant improvement resulted in the splitting tensile test, but it still managed to increase nearly 2 times higher than of its own strength. Besides, Rahai et.al. [10]also highlighted that confinement fibre in concrete significantly enhances compressive strength, stiffness, and its ductility. They also stated that the improvement of its strength was influenced by the orientation and wrapped thickness $(1,2,3$, and 4 layers) of fibre. In addition, wrapping of carbon fibre reinforced polymer (CFRP) in concrete increased the load carrying capacity of the compressive elements compared to the elements without CFRP wrapping [11].

The implementation of fibres in cement matrix basically improves the flexural strength, impact toughness, control cracking and change in failure behaviour to give post-crack load-bearing capacity and change in the flow characteristics of the fresh material [12]. High performance fibre reinforced composites are considered by complex elastic limit and strain hardening type of reaction, linked with numerous cracking. Fibermesh is a synthetic fibre that is formulated to aid cracks that occur on foamed concrete. The advantages of using fibermesh are that the mesh has cross wires that give it better pull-out-resistance. Fibermesh becomes tougher when exposed to a high load and hold the cementitious matrix to prevent the cracking from occurs. Noorsidi and Hazren [9] reported that the fibre becomes tougher because when a crack in a matrix reaches a fibre, it continues along the fibre rather than through it. This increases the area of the tip of the cracking making the possibility of crack propagation low. Besides, when the fibre-wrapped concrete is subjected to an axial compressive loading, the concrete core expands laterally. This expansion is resisted by the FRP wrap, and therefore, the concrete core is changed to a threedimensional compressive stress state[9]. Moreover, alkali resistance is one of its characteristics that can avoid the corrosion attacks in foamed concrete. The corrosion problem in concrete can cause crack to occur which shortens the life span of a building element.

Hence, this research attempts to evaluate and investigate the effectiveness of fibermesh enclosure in foamed concrete for axial strength, shear strength and flexural strength enhancement. The effect of the number of layers of fibermesh confined foamed concrete will also be observed.

\section{METHODOLOGY}

\section{Materials}

\section{Cement}

Ordinary Portland Cement (OPC) was used as the main binder in this research. The cement used in this experiment is the 'Castle' brand cement produced by the Cement Industry of Malaysia. The chemical composition of this OPC complies with the specifications of Type 1 Portland Cement in ASTM C150-4[13].

\section{Fine Sand}

Dry fine sand was sieved manually through $1.18 \mathrm{~mm}$ sieve and only $100 \%$ fine sand that passed through the sieve was used as a filler in this study which complied with ASTM C778-06[14]. Based on the research conducted by Nambiar and Ramamurthy[15], fine sand produced better strength in foamed concrete. This is because the application of coarse sand in foamed concrete will cause the pores to become bigger and create an inconsistent mix.

\section{Water}

The water to cement ratio was maintained constantly at 0.45 as prescribed in the previous study [16]. This ratio has achieved the desire workability of foamed concrete. A tap water was used to create a slurry mixture fulfils the requirement by ASTM C1602[17].

\section{Foam}

Pre-formed foam produced by a foam generator was applied in this study. NORAITTE PA-1 was used as a foaming agent to produce stable foams where $30 \mathrm{~L}$ of water is needed to dissolve $1 \mathrm{~kg}$ of foaming agent. The range of density of the foam was in between 65 to $75 \mathrm{~g} / \mathrm{L}$, this is to get the target density of foamed concrete $\left(800 \mathrm{~kg} / \mathrm{m}^{3}\right.$, $1100 \mathrm{~kg} / \mathrm{m}^{3}$ and $1400 \mathrm{~kg} / \mathrm{m}^{3}$ ).

\section{Fibermesh}

The enclosure of the fibermesh ( $160 \mathrm{~g} / \mathrm{sq} . \mathrm{m})$ is the main part of this research. This fibermesh (Figure 1) was supplied by TKS Bio Sdn. Bhd. The 3 enclosure of fibermesh in foamed concrete was to enhance its strength because it is very weak in the tensile zone. It is also designed to address early aged of cracking occurs and arrest the propagation of crack in plastic state. The advantage of using this fibermesh is it creates a three-dimensional support network that withstands the downward pull of gravity and contributes to uniform bleeding[18]. Table 1 shows the technical specification of fibermesh provided by the supplier. 


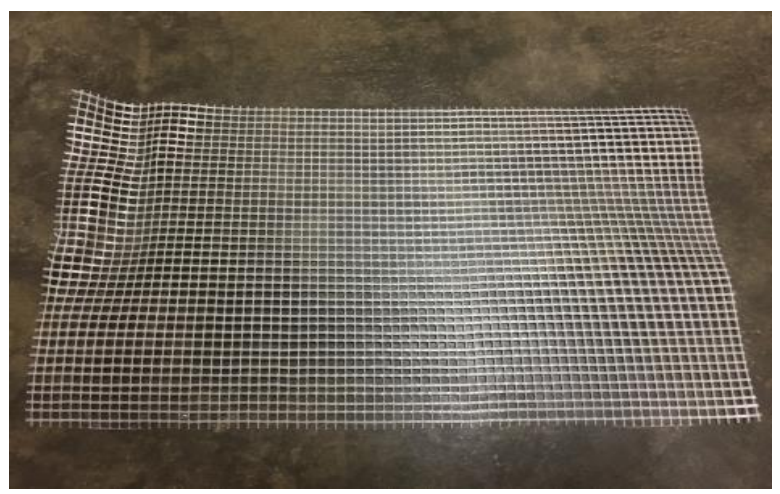

Fig.1 Fibermesh of $160 \mathrm{~g}$ per square meter weight

Table. 1 Technical specification of fibermesh provided by TKSS Bio Sdn. Bhd

\begin{tabular}{cc}
\hline Technical Specification & Detail \\
\hline Quality Assured Facility & ISO $9001: 2008$ \\
Mesh size & $4 \mathrm{~mm} \mathrm{x} 4 \mathrm{~mm}$ \\
Weight per square meter & $160 \mathrm{~g} / \mathrm{m}^{2}$ \\
Ignition Point & $759.2^{\circ} \mathrm{F}\left(404^{\circ} \mathrm{C}\right)$ \\
Melt Point & $320^{\circ} \mathrm{F}\left(160^{\circ} \mathrm{C}\right)$ \\
Specific Gravity & 0.91 \\
Compliance & ASTM C $1116 / \mathrm{C} 1116 \mathrm{M}$ \\
\hline
\end{tabular}

(Figure 2a) and splitting tensile test (Figure 2c), the fibermesh was placed around the specimen, while for the flexural test (Figure 2b) it was located at the middle of the specimen. The fibermesh was laid by layer(s) in respective densities.

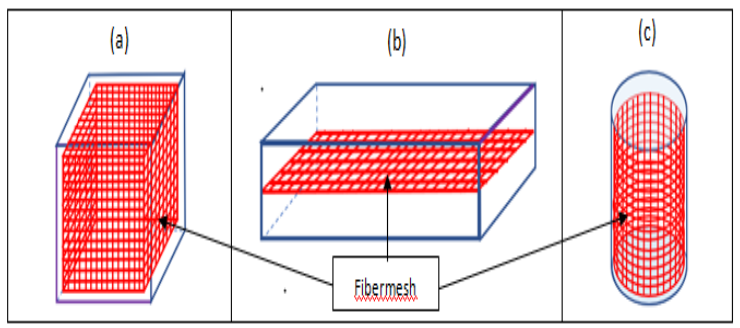

Fig. 2 Position of fibermesh in specimen

\section{Mix Design}

There was a total of 12 mixes prepared for this study. Table 2 shows the mix design for $800 \mathrm{~kg} / \mathrm{m}^{3}, 1100 \mathrm{~kg} / \mathrm{m}^{3}$ and $1400 \mathrm{~kg} / \mathrm{m}^{3}$ density of foamed concrete. $160 \mathrm{~g} / \mathrm{sq} . \mathrm{m}$ of fibermesh was added to the respective densities with different layers as shown in the Table 2. The cement-sand ratio was constantly maintained at $1: 1.5$ and the water to cement ratio was fixed at 0.45 .

The position of fibermesh is placed based on the experiment test program. For the compressive strength test

Table. 2 Mix Design

\begin{tabular}{|c|c|c|c|c|c|c|}
\hline $\begin{array}{c}\text { Density } \\
\left(\mathbf{k g} / \mathbf{m}^{\mathbf{3}}\right)\end{array}$ & $\begin{array}{c}\text { Fibermesh } \\
(\text { weight/sq.m) }\end{array}$ & $\begin{array}{c}\text { Fibermesh } \\
(\mathbf{L a y e r})\end{array}$ & $\begin{array}{c}\text { Mix Ratio } \\
(\mathbf{C : S : W})\end{array}$ & $\begin{array}{c}\text { Cement } \\
(\mathbf{K g})\end{array}$ & $\begin{array}{c}\text { Fine Sand } \\
(\mathbf{K g})\end{array}$ & $\begin{array}{c}\text { Water } \\
(\mathbf{K g})\end{array}$ \\
\hline \multirow{4}{*}{$\mathbf{8 0 0}$} & - & - & $1: 1.5: 0.45$ & 30.25 & 45.37 & 13.61 \\
\cline { 2 - 7 } & 160 & 1 & $1: 1.5: 0.45$ & 30.25 & 45.37 & 13.61 \\
\cline { 2 - 7 } & 160 & 2 & $1: 1.5: 0.45$ & 30.25 & 45.37 & 13.61 \\
\cline { 2 - 7 } & 160 & 3 & $1: 1.5: 0.45$ & 30.25 & 45.37 & 13.61 \\
\cline { 2 - 7 } & - & - & $1: 1.5: 0.45$ & 41.08 & 61.62 & 18.49 \\
\cline { 2 - 7 } & 160 & 1 & $1: 1.5: 0.45$ & 41.08 & 61.62 & 18.49 \\
\cline { 2 - 7 } & 160 & 2 & $1: 1.5: 0.45$ & 41.08 & 61.62 & 18.49 \\
\hline \multirow{4}{*}{$\mathbf{1 4 0 0}$} & 160 & 3 & $1: 1.5: 0.45$ & 41.08 & 61.62 & 18.49 \\
\cline { 2 - 7 } & - & - & $1: 1.5: 0.45$ & 51.91 & 77.87 & 23.36 \\
\cline { 2 - 7 } & 160 & 1 & $1: 1.5: 0.45$ & 51.91 & 77.87 & 23.36 \\
\cline { 2 - 7 } & 160 & 2 & $1: 1.5: 0.45$ & 51.91 & 77.87 & 23.36 \\
\hline
\end{tabular}

\section{Compressive Strength Test}

The compressive strength of the foamed concrete was determined by using a $100 \times 100 \times 100 \mathrm{~mm}$ cube as prescribed in BS EN12390-Part 3[19]. The specimens were tested by using a universal testing machine (GTECH GT-7001BS300) with the capacity of $3000 \mathrm{kN}$ (refer to Figure 3). 3 specimens were examined for each curing age (day-7, day28 , day-60 and day-180). The average value of these three tested specimens were recorded as a result of the compressive strength test.

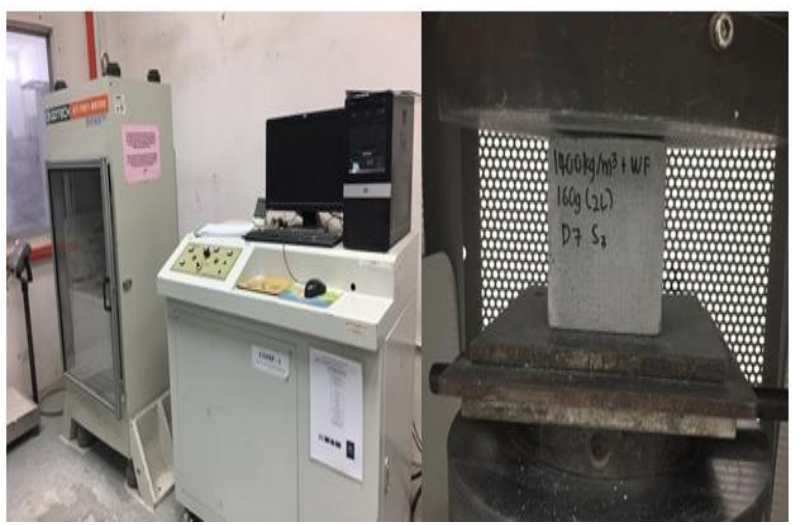

Fig. 3 Compressive strength test 


\section{Flexural Strength Test}

The flexural strength of foamed concrete was performed by using the three-point bending method as guided by ASTM C348[20]. The size of samples used was 40x40x $160 \mathrm{~mm}$ prisms. 3 samples for each age of curing (day-7, day-28, day-60, and day180) were tested using the universal testing machine (refer to Figure 4).

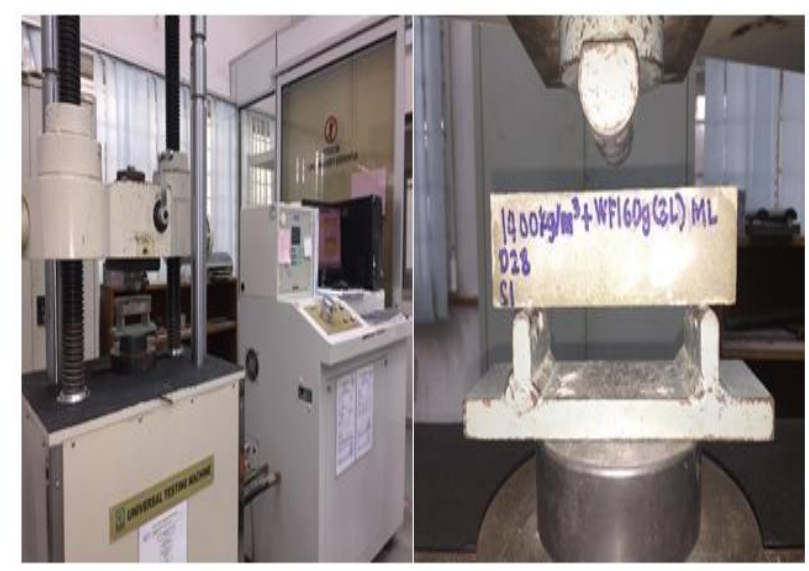

Fig. 4 Flexural strength test (3-point bending)

\section{Splitting Tensile Strength Test}

Splitting tensile test was examined according to ASTM shows the positions of specimens while using the testing machine.

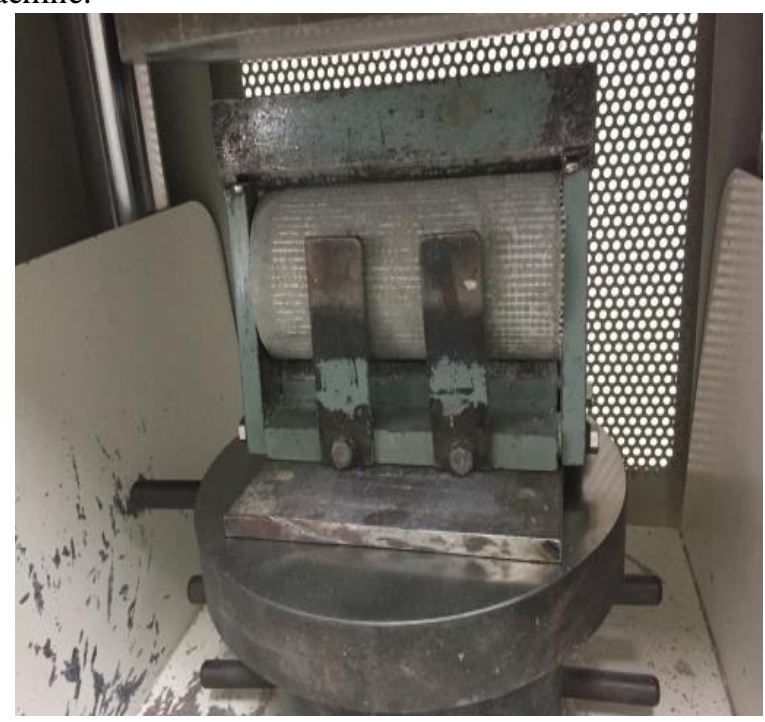

Fig. 5 Splitting tensile test setup

\section{RESULTS}

This section will present the results of the mechanical properties obtained through laboratory investigation. Table 3 , Table 4 and Table 5 summarized the compressive strength, flexural strength and tensile strength of all three densities $\left(800 \mathrm{~kg} / \mathrm{m}^{3}, 1100 \mathrm{~kg} / \mathrm{m}^{3}\right.$ and $1400 \mathrm{~kg} / \mathrm{m}^{3}$ casted and tested for this study) correspondingly. The specimens were tested at day-7, day-28, day-60 and day-180. Based on Table

\begin{tabular}{|l|l|l|}
\hline Density $\left(\mathrm{kg} / \mathrm{m}^{3}\right)$ & Specimen & Compressive Strength $\left(\mathrm{N} / \mathbf{m m}^{2}\right)$ \\
\hline
\end{tabular}

C496/C496M-17[21]. The size of specimen was 100mm diameter $\mathrm{x} 200 \mathrm{~mm}$ height measured using the universal testing machine (GTECH GT-7001-BS300). The test was conducted at day-7, day-38, day-60 and day-180, the average value of the three specimens were taken as representatives of splitting tensile strength results. Figure 5
3, Table 4 and Table 5, the control specimen present the foamed concrete without any addition of fibermesh while 1L-FM, 2L-FM and 3L-FM are 1 layer, 2 layers and 3 layers of foamed concrete enclosure with fibermesh respectively

\section{Table. 3 Compressive strength results}


International Journal of Recent Technology and Engineering (IJRTE)

ISSN: 2277-3878, Volume-8, Issue-2S2, July 2019

\begin{tabular}{|c|c|c|c|c|c|}
\hline & & 7-day & 28-day & 60-day & 180-day \\
\hline \multirow{4}{*}{800} & Control & 0.98 & 1.25 & 1.39 & 1.52 \\
\hline & 1L-FM & 1.48 & 2.07 & 2.24 & 2.39 \\
\hline & 2L-FM & 2.10 & 2.63 & 2.84 & 3.01 \\
\hline & 3L-FM & 2.73 & 3.58 & 3.76 & 3.98 \\
\hline \multirow{4}{*}{1100} & Control & 2.88 & 3.44 & 3.72 & 3.76 \\
\hline & 1L-FM & 3.67 & 5.09 & 5.44 & 5.87 \\
\hline & 2L-FM & 4.11 & 5.76 & 6.01 & 6.54 \\
\hline & 3L-FM & 4.68 & 6.45 & 7.04 & 7.39 \\
\hline \multirow{4}{*}{1400} & Control & 5.87 & 6.56 & 6.99 & 7.32 \\
\hline & 1L-FM & 7.83 & 10.33 & 10.96 & 11.77 \\
\hline & 2L-FM & 8.99 & 11.27 & 11.98 & 13.04 \\
\hline & 3L-FM & 9.87 & 12.87 & 13.53 & 14.36 \\
\hline
\end{tabular}

Table. 4 Flexural strength results

\begin{tabular}{|c|c|c|c|c|c|}
\hline \multirow[t]{2}{*}{ Density $\left(\mathrm{kg} / \mathrm{m}^{3}\right)$} & \multirow[t]{2}{*}{ Specimen } & \multicolumn{4}{|c|}{ Compressive Strength $\left(\mathrm{N} / \mathrm{mm}^{2}\right)$} \\
\hline & & 7-day & 28-day & 60-day & 180-day \\
\hline \multirow{4}{*}{800} & Control & 0.19 & 0.28 & 0.31 & 0.36 \\
\hline & 1L-FM & 0.51 & 0.71 & 0.77 & 0.88 \\
\hline & 2L-FM & 0.75 & 0.91 & 0.99 & 1.11 \\
\hline & 3L-FM & 1.17 & 1.47 & 1.61 & 1.74 \\
\hline \multirow{4}{*}{1100} & Control & 0.59 & 0.71 & 0.78 & 0.83 \\
\hline & 1L-FM & 1.16 & 1.61 & 1.73 & 1.88 \\
\hline & 2L-FM & 1.44 & 1.98 & 2.08 & 2.32 \\
\hline & 3L-FM & 1.86 & 2.51 & 2.79 & 2.97 \\
\hline \multirow{4}{*}{1400} & Control & 1.06 & 1.19 & 1.28 & 1.38 \\
\hline & 1L-FM & 2.29 & 3.03 & 3.19 & 3.44 \\
\hline & 2L-FM & 3.16 & 3.95 & 4.22 & 4.61 \\
\hline & 3L-FM & 4.08 & 5.31 & 5.59 & 5.96 \\
\hline
\end{tabular}

Table. 5 Tensile strength results

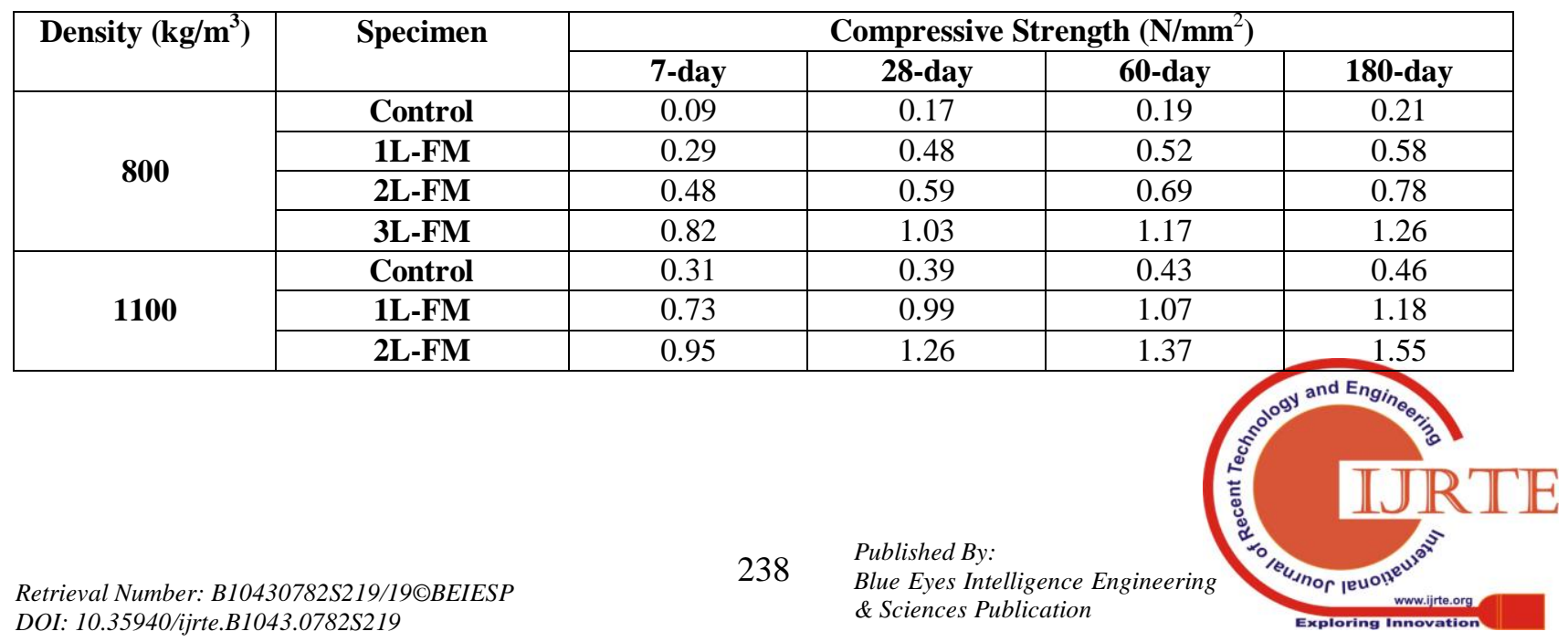


Enhancement of Mechanical Properties of Lightweight Foamed Concrete using Fibermesh

\begin{tabular}{|c|c|c|c|c|c|}
\hline & 3L-FM & 1.31 & 1.75 & 1.95 & 2.04 \\
\hline \multirow{3}{*}{1400} & Control & 0.58 & 0.69 & 0.73 & 0.81 \\
\cline { 2 - 6 } & 1L-FM & 1.47 & 1.95 & 2.05 & 2.22 \\
\cline { 2 - 6 } & 2L-FM & 2.13 & 2.66 & 2.85 & 3.11 \\
\cline { 2 - 6 } & 3L-FM & 2.88 & 3.74 & 3.93 & 4.22 \\
\hline
\end{tabular}

\section{Compressive Strength}

The compressive strength of foamed concrete with three different densities were demonstrated in Figure 6,7 and 8. At the early age of curing, the compressive strength of foamed concrete is low because the concrete has not fully hardened. Many researchers agreed that at day-28, the concrete is $100 \%$ hardened. This is because curing is the period of time when concrete gains its strength by preventing loss of moisture contents which leads to cracking in concrete [22]. Awang et.al[23]also stated that in their study, there is an enhancement of strength from day-7 to day- 90 of tested age and the possibility of strength increased according to age. In these three figures, it shows that 3L-FM has the highest compressive strength compared to other specimens at the same density of day-180 where at density $800 \mathrm{~kg} / \mathrm{m}^{3}$, the compressive strength is $3.98 \mathrm{~N} / \mathrm{mm}^{2}$, while $7.38 \mathrm{~N} / \mathrm{mm}^{2}$ and $14.36 \mathrm{~N} / \mathrm{mm}^{2}$ for foamed concrete with densities of $1100 \mathrm{~kg} / \mathrm{m}^{3}$ and $1400 \mathrm{~kg} / \mathrm{m}^{3}$ respectively.

The reason of the foamed concrete strength increase is due to the role of fibermesh that acts as an anti-micro-crack and prevents the widening of cracks when the load is

applied[24]. Besides, the highest density shows the highest strength of foamed concrete because it only requires a small volume of foam to be added and vice versa to low density where more foam is needed to get the lower density of foamed concrete. When more foamed concrete is inserted in the mixture, it means that the concrete contains a lot of air void that can cause foamed concrete to become weaker than foamed concrete with a high density.

In addition, the result shows significant improvement of compressive strength in foamed concrete with the enclosure of fibermesh. There was a $60.79 \%$ increase of foamed concrete strength after confinement of fibermesh (1L-FM) compared to the controlled mix at a density of $1400 \mathrm{~kg} / \mathrm{m}^{3}$ and day-180. This finding is the same as the finding from are search conducted by Othuman Mydin et. al [25], they found that by adding fibre in foamed concrete, its strength increased up to $21 \%$ compared to a control mix.

This improvement continues to increase up to $10.8 \%$ with the inclusion of 2 layers of fibermesh (2L-FM) and also an increase in strength by two times after 3 layers of fibermesh were added where it increased $22 \%$ from $1 \mathrm{~L}-\mathrm{Fm}$ to $3 \mathrm{~L}-\mathrm{FM}$ $\left(14.36 \mathrm{~N} / \mathrm{mm}^{2}\right)$ and became the highest result of compressive strength in this study (refer to Figure8). The improvement happened because the fibermesh bonded with the cementitious matrix to create a stronger foamed concrete. This has been proved by Noorsidi and Hazren [9] in their study, where there is an increment of 54\% was achieved between 1 layer and 2 layers of fibre in the compressive strength test. Thus, the compressive strength of foamed concrete was increased when the fibre was applied in the matrix. The fibres confine the foamed concrete and increase the axial strength by creating a triaxial stress condition. The fibermesh wraps also increase the shear resistance of foamed concrete and prevent premature failures when subjected to lateral loadings

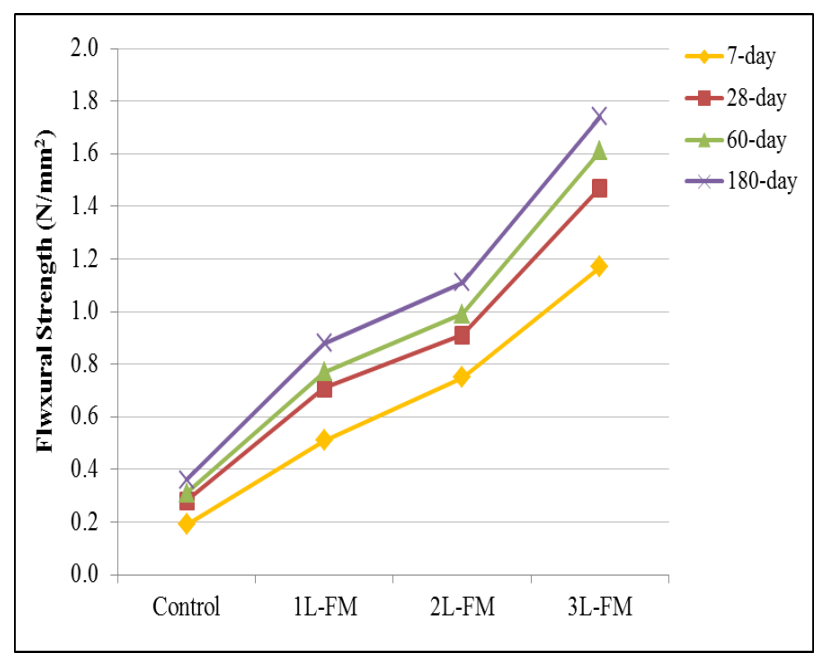

Fig. 6 Compressive strength of $800 \mathrm{~kg} / \mathrm{m}^{3}$ density lightweight foamed concrete with different layers of fibermesh

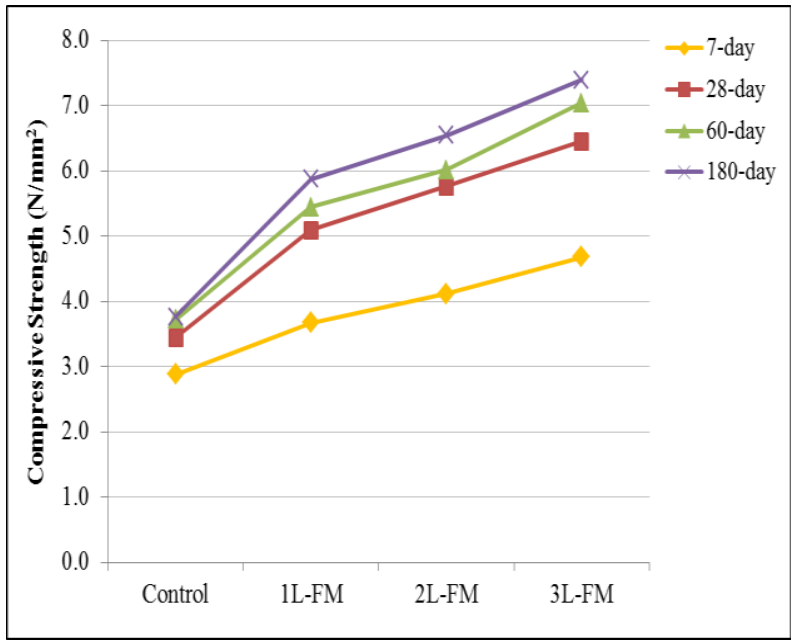

Fig. 7 Compressive strength of $1100 \mathrm{~kg} / \mathrm{m}^{3}$ density lightweight foamed concrete with different layers of fibermesh 


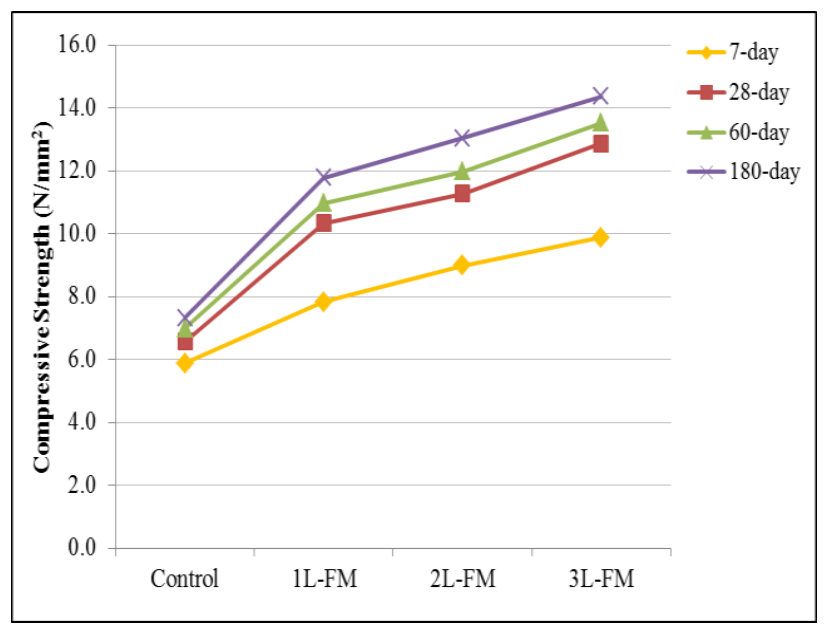

Fig. 8 Compressive strength of $1400 \mathrm{~kg} / \mathrm{m}^{3}$ density lightweight foamed concrete with different layers of fibermesh

\section{Flexural Strength}

Figures 9, 10 and 11 displays the results of flexural strength test for all foamed concrete specimens. It can be observed that fibermesh enhances the flexural strength of foamed concrete. All the specimen strength is increase according to the day of specimen tested. The flexural strength also increased from a density of $800 \mathrm{~kg} / \mathrm{m}^{3}$ to $1400 \mathrm{~kg} / \mathrm{m}^{3}$ due to the volume of air bubble in the specimen. A high volume of air bubbles in the matrix caused the foamed concrete to be more brittle and breaks easily when exposed to a high load. The strength of foamed concrete (control specimen - no fibermesh) increased to $130.6 \%$ from a density of $800 \mathrm{~kg} / \mathrm{m}^{3}$ to $1100 \mathrm{~kg} / \mathrm{m}^{3}$ and $66.3 \%$ for a density of $1100 \mathrm{~kg} / \mathrm{m}^{3}$ to $1400 \mathrm{~kg} / \mathrm{m}^{3}$. A significant increase of flexural strength in foamed concrete occurs when the fibermesh was added in the specimens. In Figure 9, it shows $144.4 \%$ enhancement of $800 \mathrm{~kg} / \mathrm{m}^{3}$ density of foamed concrete with an addition of 1-layer fibre in the specimen, while $126.5 \%$ at a density of $1100 \mathrm{~kg} / \mathrm{m}^{3}$ (Figure 10) and $149.3 \%$ at a density of $1400 \mathrm{~kg} / \mathrm{m}^{3}$ (Figure 11 ). Besides, the flexural strength of foamed concrete drastically increased with the enclosure of 3-layers of fibermesh (3L-FM) at respective densities, and $3 \mathrm{~L}-\mathrm{FM}$ at a density of $1400 \mathrm{~kg} / \mathrm{m}^{3}$ (180 days) shows the highest flexural strength compared to other results.

The increase of flexural strength in foamed concrete is because of the fibre reacting as a reinforcing membrane to bind the grid of cementitious matrix sturdily compared to the specimen without any fibre applied in the tensile zone[25]. The addition of the fibermesh not only improved the foamed concrete strength, but also shows ductile behaviour at the early stages of crack occurrence and prevents the specimen to be broken into two parts. Moreover, the enclosure of fibermesh gives better shear force by preventing the crack from occurring when the load was applied [2]. Figure 12 shows the ductility behaviour of fibermesh in foamed concrete when tested by a universal testing machine under 3-point bending.

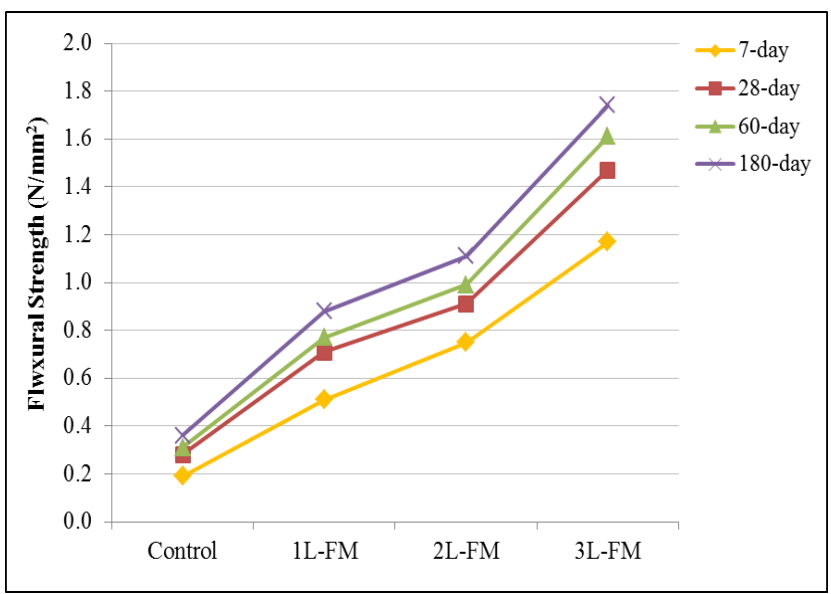

Fig. 9 Flexural strength of $800 \mathrm{~kg} / \mathrm{m}^{3}$ density lightweight foamed concrete with different layers of fibermesh

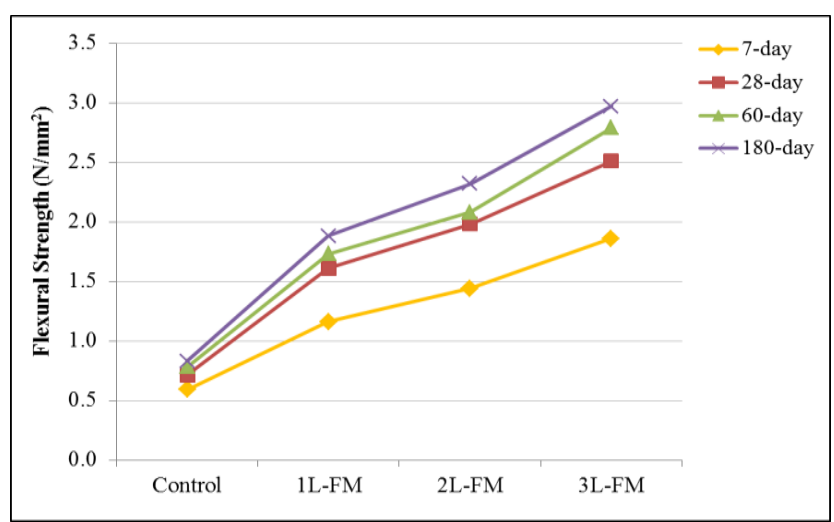

Fig. 10 Flexural strength of $1100 \mathrm{~kg} / \mathrm{m}^{3}$ density lightweight foamed concrete with different layers of fibermesh

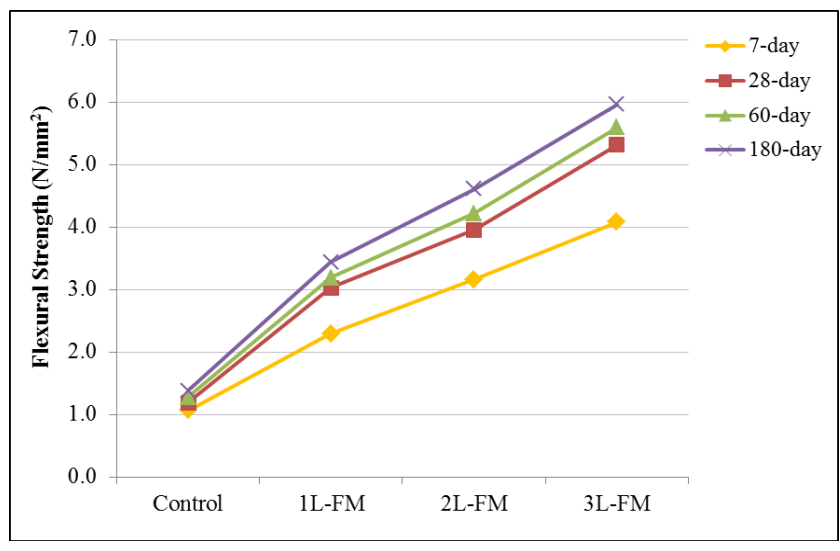

Fig. 11 Flexural strength of $1400 \mathrm{~kg} / \mathrm{m}^{3}$ density lightweight foamed concrete with different layers of fibermesh

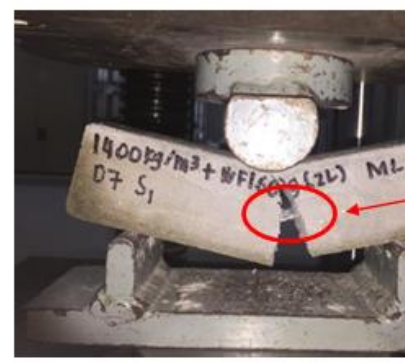

Published By: 


\section{Fig. 12 Ductility behaviour of fibermesh in foamed concrete}

\section{Tensile Strength}

Figure 13, 14 and 15 reveals the results of splitting tensile strength for foamed concrete density $800 \mathrm{~kg} / \mathrm{m}^{3}, 1100 \mathrm{~kg} / \mathrm{m}^{3}$ and $1400 \mathrm{~kg} / \mathrm{m}^{3}$. Figure 13 shows that $800 \mathrm{~kg} / \mathrm{m}^{3}$ with an enclosure of 3 layers of fibermesh distributes a better splitting tensile strength compared to control, 1L-FM and $2 \mathrm{~L}-\mathrm{FM}$ specimen with $1.26 \mathrm{~N} / \mathrm{mm}^{2}$. The strength increased to $1.05 \mathrm{~N} / \mathrm{mm}^{2}$ from the control to $3 \mathrm{~L}-\mathrm{FM}$ specimen. Meanwhile, Figure 14 shows $1100 \mathrm{~kg} / \mathrm{m}^{3}$ with an addition of 3 layers fibermesh at day-180 of test result in high tensile strength compared to others specimen with $2.04 \mathrm{~N} / \mathrm{mm}^{2}$ strength. Finally, figure 15 exhibits that 3 layers of fibermesh in foamed concrete at 180 days produced an impressive splitting tensile strength result compared to other specimens with $4.22 \mathrm{~N} / \mathrm{mm}^{2}$ strength.

Based on this result, the percentage enhancement of splitting tensile strength is sharply increased from control specimen to foamed concrete with an enclosure of fibermesh. It can be seen clearly at density $1400 \mathrm{~kg} / \mathrm{m}^{3}(180$ days) that the strength increased $174.1 \%$ from control specimen to $1 \mathrm{~L}-\mathrm{FM}$, a $40.1 \%$ enhancement from 1L-FM to 2L-FM and an increase of $35.7 \%$ from 2L-FM to 3L-FM.

The increasing trend of splitting tensile strength in foamed concrete with enclosure of fibermesh is due to the elasticity of fibre that can stretch and bond strongly with cement matrix to halt cracking from occurring. Parveen[26]also stated that in their research, the increase of splitting tensile strength is due to the holding capacity of fibres which aid the splitting of concrete. This result is the same as the finding obtained by Noorsidi and Hazren [9], where the splitting tensile test shows a $23 \%$ increment with the addition of 2 layers of Glass Fibre Reinforced Polymers in the concrete.

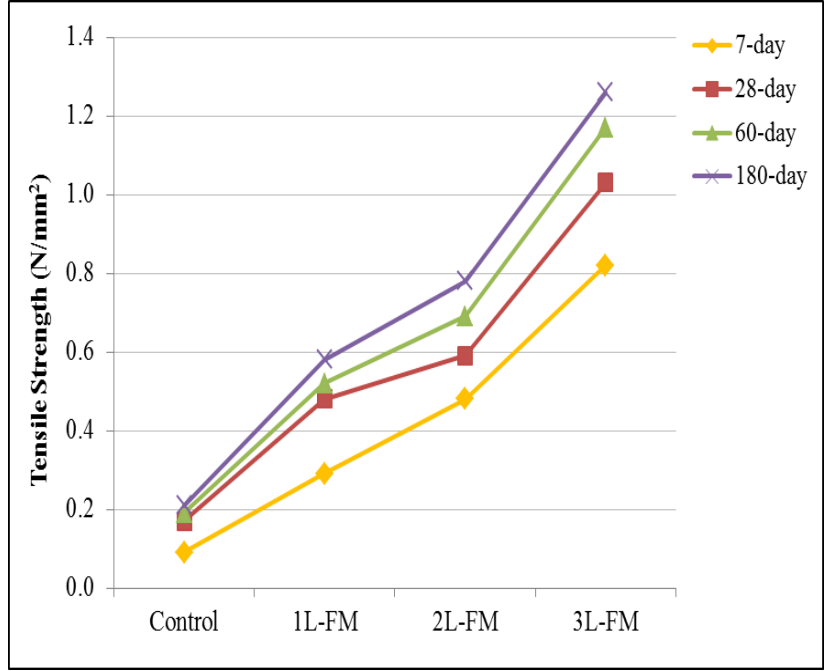

Fig. 13 Tensile strength of $800 \mathrm{~kg} / \mathrm{m}^{3}$ density lightweight foamed concrete with different layers of fibermesh

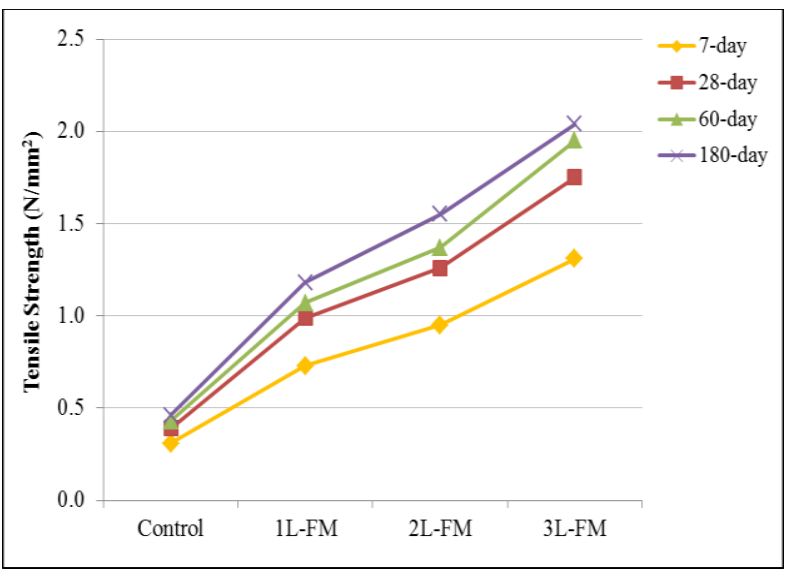

Fig. 14 Tensile strength of $1100 \mathrm{~kg} / \mathrm{m}^{3}$ density lightweight foamed concrete with different layers of fibermesh

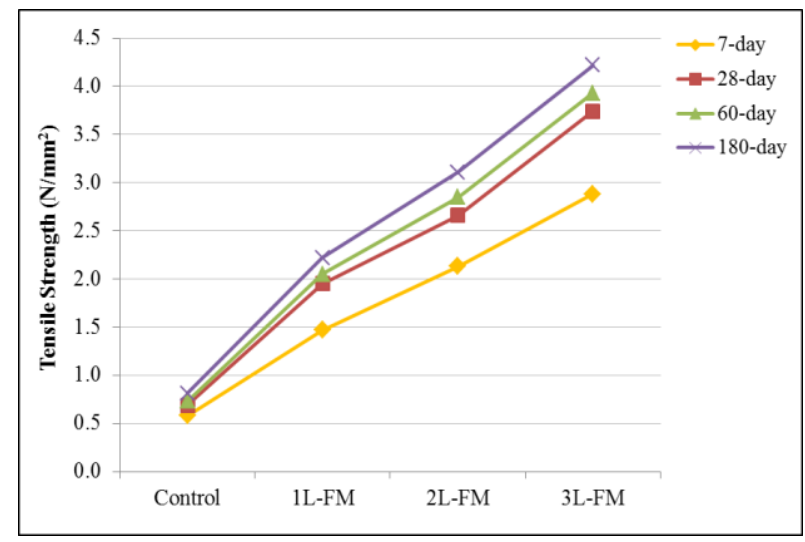

Fig. 15 Tensile strength of $1400 \mathrm{~kg} / \mathrm{m}^{3}$ density lightweight foamed concrete with different layers of fibermesh

\section{CONCLUSIONS}

Based on the analysis made, it can be concluded that the enclosure of fibermesh produced impressive enhancement in the mechanical properties of foamed concrete. The strength was increased as the curing aged days increased. Besides, it can be drawn that the foamed concrete strength was reduced when the volume of foam added is a lot since more air bubble in matrix will caused the foamed concrete more brittle and breakdown easily. In this study, $1400 \mathrm{~kg} / \mathrm{m} 3$ showed the best result compared to other densities. The addition of more than 1 fibermesh also created a better bonding in the cementitious matrix. At a density of $1400 \mathrm{~kg} / \mathrm{m} 3$ (day-180), there are drastic improvements of strength in foamed concrete, where $96.2 \%$ strength of foamed concrete is increased between control specimen with 3 layers addition of fibermesh in compressive strength while $332 \%$ in flexural strength and $421 \%$ in splitting tensile strength. Hence, an enclosure of fibermesh in foamed concrete leads to a positive impact in its mechanical properties and increased the foamed concrete's strength.

\section{ACKNOWLEDGEMENT}


The authors would like to thank Universiti Sains Malaysia for their funding of this research through the Bridging Grant (304 / PPBGN / 6316230)

\section{REFERENCES}

1. R., Rostami, S.M., Koshnava, A., Ahankoob, R., Rostami. 2008. "Green construction Trends in Malaysia." Management in Construction Research Association (MiCRA) Postgraduate Conference.

2. M. A., Othuman Mydin, N. A., Rozlan, S., Ganesan. 2015. "Experimental study on the mechanical properties of coconut fiber reinforced lightweight foamed concrete." Journal of Materials and Environmental Science. 6(2):407-411

3. Deijik S, Van. 1991. Foam Concrete.

4. Solemazadeh, S., and M. A Othuman Mydin. 2013. "Influence of High Temperatures on Flexural Strength of Fomaed Concrete Containing Fly Ash and Polypropylene Fiber.” Int. Journal of Engineering 26(1): 36574.

5. Meheddene, M, B Hisham, Hadi A.C, and E Adel. 2014. "Alkali Treatment of Fan Palm Natural Fibers for Use in Fiber Reinforced Concrete." European Scientific Journal 10(2): 186-94.

6. K.C., Brady, G.R.A., Watts, M.R., Jones. 2001. "Specification for foamed concrete." pp. 5-12

7. Y.H.M. Amran, N.Farzadnia, A.A.Abang Ali. 2015. "Properties and applications of foamed concrete; review". Construction and Building Materials 101:990-1005.

8. M., Murugan, C., Natarajan, K., Muthukkumaran. 2013. "Compressive Behavior of Concrete Cylinders Confined with Glass and Carbon Fiber Reinforced Polymers." International Journal of Structural and Civil Engineering Research. 2(2):69-76.

9. M.N., Noorsidi Aizuddin, M., Hazren. "Fiber Reinforced Polymer Concrete Structures - Opportunities and Concerns."

10. A.R., Rahai, P., Sadeghaian, M.R. Ehsani. 2008. "Experimental Behavior of Concrete Cylinders Confined with CFRP Composites". The $14^{\text {th }}$ World Conference on Earthquake Engineering.

11. P.R., Prasad, B.M., Reddy. 2016. "Improvement of Compressive Strength of Reinforced Cement Concrete Elements Using CFRP wrapping." Int. Journal of Latest Trends in Engineering and Technology (IJLTET). 6(4):53-79.

12. Bashar, I.I., Alengaram, U.J., Jumaat, M.Z., Islam, A, Santhi, H., Sarmin, A. 2016. "Engineering properties and fracture behaviour of high volume palm oil fuel ash based fiber reinforced geopolymer concrete." Construction and Building Materials 111:286-297.

13. ASTM. 2005. "Standard Specification for Portland Cement ASTM C150." Annual Book of ASTM Standards. 04(02).

14. ASTM. 2005. "Standard Specification for Standard Sand." Annual Book of ASTM Standards. 04(02).

15. Nambiar, E.K.K., Ramamurthy, K. 2006. "Influence of filler type on the properties of foam concrete". Cement and Concrete Composites. 28(5):474-480.

16. Talaei, S., Jafri, M., M., Tarfan, S., Hashemlou, H. 2014. "The Effect of ratio of Aggregate to Cement Paste Volume on Structural Lightweight Concrete Strength Viscosity, Density and Cost. 6(9):443450.

17. ASTM. 2005. "Specification for Mixing Water Used in the Production of Hydraulic Cement Concrete." Annual Book of ASTM Standards. 04(02).

18. M.A., Othuman Mydin, M., Musa, A.N., Abdul Ghani. 2018. "Fiber Glass Strip Laminates Strengthened Lightweight Foamed Concrete: Performance Index, Failure Modes and Microscopy Analysis." AIP Conference Proceedings 2016 (September). 1-8

19. British Standard Institution. 2009. "BS EN 12390-3 Testing Hardened Concrete Part 3: Compressive Strength of Test Specimens." British Standard Institution.

20. ASTM C348. 2002. "Flexural Strength of Hydraulic-Cement Mortars." ASTM International 04: 1-6.

21. ASTM C496. 2006. "Standard Test Method for Splitting Tensile Strength of Cylindrical Concrete Specimens." ASTM International. 15.

22. A.A., Raheem, A.A., Soyingbe, A.J., Emenike. 2013. "Effect of Curing Methods on Density and Compressive Strength of Concrete." Cement and Concrete Composites. 3(4):55-64.

23. H., Awang, M.H., Ahmad, M.Z., Al-Mulali. 2015. "Influence of Kenaf and Polypropylene Fibers of Reinforced Lightweight Foamed
Concrete." Journal of Engineering Science and Technology. 10(4):496508 .

24. J., Norgaard, M. A., Othuman Mydin. 2013. "Drywall Thermal Properties Exposed to High Temperatures and Fire Condition.” Jurnal Teknologi 62(1) 63-68

25. R. Kolopm Haziman W.I.M., J.W. Eng. 2008. "Properties of Cement Blocks Containing High Content of Oil Palm Empty Fruit Bunches (EFB) Fibers."

26. Parveen, S. Sharma. 2013. "Structural Behaviour of Fibrous Cement Using Polypropylene Fibers." International Journal of Modern Engineering Research (IJMER)3(3):1279-1282. 